\title{
FORMULATION OF A COMPLEMENTARY FOOD FORTIFIED WITH BROAD BEANS (Vicia faba) IN SOUTHERN ETHIOPIA
}

\section{Kebebu A ${ }^{1}$,Whiting SJ ${ }^{2 *}$, Dahl WJ ${ }^{3}$, CJ Henry ${ }^{4}$ and A Kebede ${ }^{5}$}

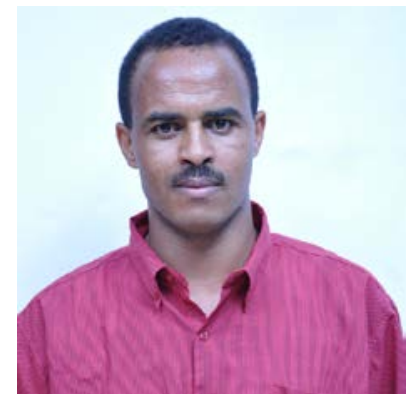

Afework Kebebu

* Corresponding author email: susan.whiting@usask.ca

${ }^{1}$ MSc Research Assistant, School of Food Science and Nutrition, Hawassa University, Awassa Ethiopia

${ }^{2}$ PhD Professor, College of Pharmacy and Nutrition, University of Saskatchewan, Saskatoon SK, S7N 5C9 Canada

${ }^{3}$ PhD RD Assistant Professor, Food Science and Human Nutrition Department, University of Florida, Gainesville, USA

${ }^{4} \mathrm{PhD}$ Associate Professor, College of Pharmacy and Nutrition, University of Saskatchewan, Saskatoon SK, S7N 5C9 Canada

${ }^{5} \mathrm{PhD}$, Assistant Professor, Hawassa University, Awass Ethiopia. 


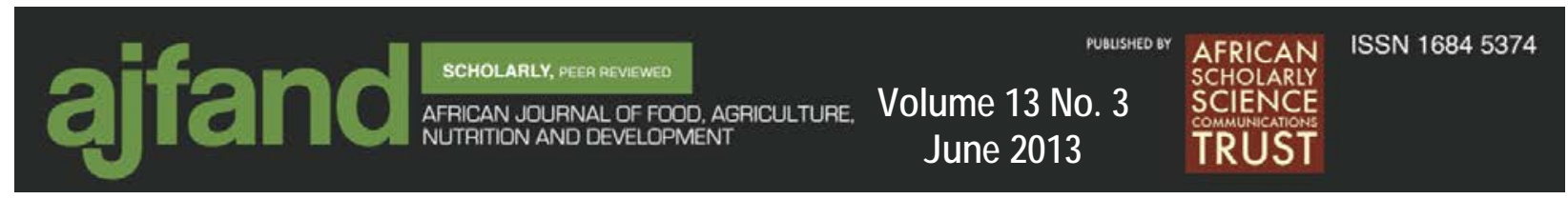

\begin{abstract}
Adequate nutrient intake, especially of protein and micronutrients, enhances growth of children and decreases susceptibility to disease. Major contributing factors to malnutrition among infants and children are low purchasing power of the family resulting in poor quality foods. A cross-sectional and laboratory-based study was conducted at Titecha Kebele in Ethiopia to assess the consumption pattern of broad bean. The work also assessed use of broad bean for complementary feeding of young children, following $\mathrm{FAO} / \mathrm{WHO} / \mathrm{UNU}$ 's recommendation of adding up to a maximum of $40 \%$ legumes to cereal-based complementary food for young children. Study participants were mother-child pairs ( $n=169)$, and children were between 6-35 months of age. Most families were in poverty with stunting, wasting, and underweight present in 22.5, 4.7, and $8.3 \%$ of study children, respectively. Questionnaires gathered information on dietary intakes, and focus group discussions were used to obtain indepth information on the mother's attitude and knowledge of child feeding, as well as overall consumption of broad beans. The mean dietary diversity score of children was approximately two out of a possible eight, and no child had consumed meat, fish, or vitamin A-containing fruits or vegetables the day before the study. Sixty percent of mothers did not provide bean-based food for their children, with the most frequently reported reason being lack of knowledge of its nutrient value for young children. To a typical complementary food of barley-maize porridge, 10, 20 and 30\% of cereal was replaced by processed broad beans (Vicia faba), which increased in protein content, with no meaningful change in phytate content. Sensory evaluation showed that participant children and mothers preferred the taste of the $10 \%$ broad bean porridge; however, all added broad bean porridges had similar acceptability to the barley-maize control. Thus, inclusion of processed broad bean can effectively be done to improve nutrient content and nutrient availability of traditional cereal-based complementary foods in the Titecha kebele region of Ethiopia.
\end{abstract}

Key words: legumes, pulses, phytate, Ethiopia, diversity 


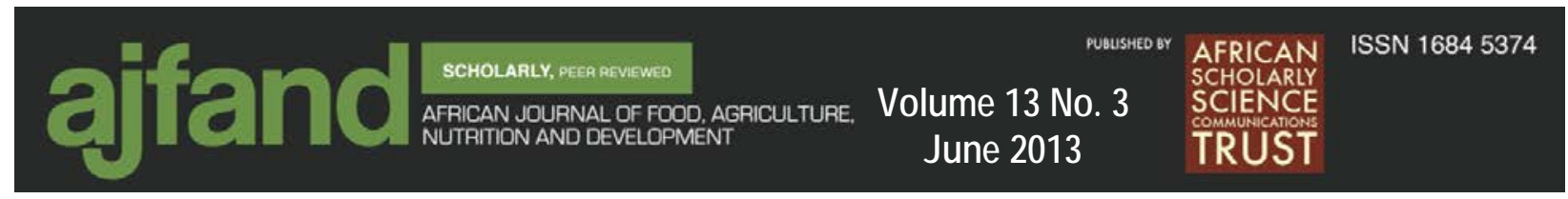

\section{INTRODUCTION}

High malnutrition rates in Ethiopia pose a significant burden in economic and social development [1]. Major contributing factors to malnutrition among infants and children are poverty and low purchasing power of the family [2]. Food-based strategies are key to addressing hunger and malnutrition, and the desired characteristics of foods include high nutrient density, low bulk property, as well as utilization of low cost and locally-available crops. This will ensure early adoption at home and at the village level [3]. Despite children's high requirements for nutrients, their diets in developing countries are mostly comprised of cereals or starchy root crops which, when eaten exclusively, result in deficiencies of key nutrients such as iron, zinc, calcium, riboflavin, vitamin A, and vitamin C [4]. Although Ethiopia has a fairly large livestock population, availability of meat and milk for local human consumption is limited, especially in rural areas where wealth index values are in the lower quintiles, according to the most recent Demographic and Health Survey [5].

Beans (including dried peas, also known as pulses) have several important attributes including high nutritional value, long storage times and relatively low cost in comparison to animal products. Beans make an important contribution in protein, energy and micronutrient provision to populations in the developing world [6]. Beans are extremely diverse crops in terms of cultivation methods, uses, and the range of environments to which they have been adapted. Beans provide dietary protein that play essential role in human nutrition, especially in combination with other foods [7]. Complementary foods can be prepared by mixing cereal grain products with locallyavailable legume grain products to produce foods with adequate energy and protein levels. Applications of food processing techniques like germination and fermentation both minimizes antinutritional factors and enhances nutrient intake and palatability [8]. The broad bean, Vicia faba, also known as the fava bean, is a species of bean grown in various parts of Ethiopia; however, consumption of legumes is not widely practiced in Ethiopia. For example, only $20 \%$ of young children eat complementary foods prepared from legumes, with most consuming cereal-based foods but little or no added animal foods [5].

Stunting is a recognized problem in Ethiopia, which is related to the high cost of protein-based foods [9]. In 2010, the prevalence of stunting, wasting and underweight in Ethiopian children under five years of age was 44.4, 9.7 and 28.7\%, respectively [5]. Micronutrient deficiencies including iron and zinc are also recognized as problems in many parts of Ethiopia, including the southern region of Southern Nation Nationalities and Peoples Region (SNNPR), and especially in young children $[10,11,12]$. In order to overcome these nutritional problems, consideration of locally available, affordable and relevant sources of food is important. The recommendations from $\mathrm{FAO} / \mathrm{WHO} / \mathrm{UNU}$ to add a maximum of $40 \%$ legumes to cereal-based complementary food for young children has been made [13]. However, the feasibility and acceptability of this recommendation deserves testing in Ethiopia, where beans are locally grown and relatively inexpensive (compared to meat). Thus, the aim of this

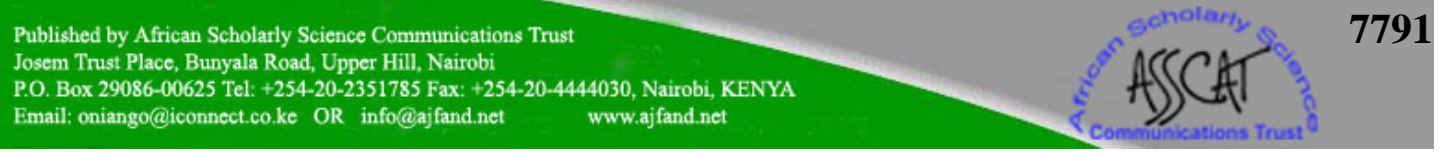




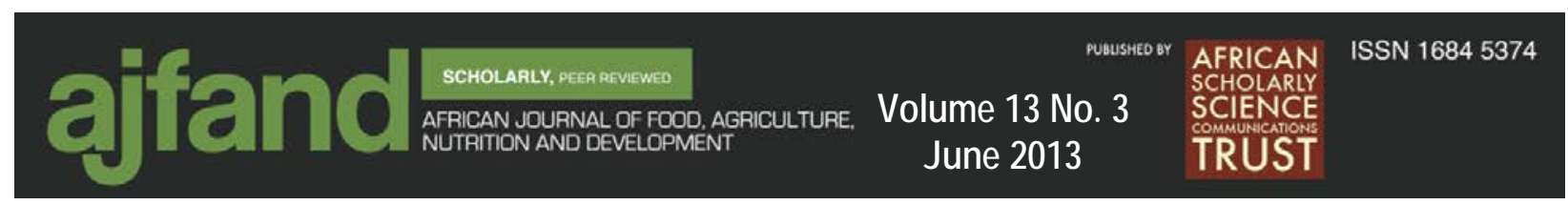

study was to formulate and then test acceptability of a bean-based complementary food using broad beans, which are widely available but not well-consumed, especially in rural areas in Southern Ethiopia.

\section{METHODS}

This study was conducted during March 2011 in a region (Woreda) of Ethiopia called Hula, a township (kebele) called Titecha, which is in the Southern Nations, Nationalities and Peoples' Region (SNNPR) Sidama zone. This area is located $91 \mathrm{~km}$ from the city of Hawassa. According to Ethiopian population and housing census data from 2007, the total population of Hula Woreda was 130,433 of which 95 \% reside in rural communities [14]. Local officials indicated the total population of the Kebele of Titecha at the end of August 2010 was 4,970, with $15 \%$ under five years of age. Important cash crops include maize, wheat, barley, potatoes, cabbage, and broad bean (also known as fava bean); however, the main crop of Titecha Kebele is enset, also called "false banana" (Enset ventricosum) which is used to make high starch food called Kocho [15].

Titecha was selected for this study because of its potential for growing beans, and the presence of food insecurity with a high number of malnourished children. This study was conducted in a single Kebele containing 16 villages (called gottes). All households with young children were identified by using immunization cards from the health center and house-to-house requests. The first household was selected by lottery method after determining total number of study participants for that specific gotte.

\section{Study design}

This study had two major components. First, there was a cross sectional survey of 169 mother-child pairs to assess socio-demographic, child feeding practices, pulse consumption and anthropometric status of young children. Second, ingredient processing and development of a broad bean fortified complementary food including evaluation for its energy and nutrient content as well as acceptability using sensory testing in the community. Laboratory work was done at Hawassa University Food Science Laboratory and Ethiopian Health and Nutrition Research Institute (EHNRI) Addis Ababa. Ethical approval was obtained from Hawassa University ethical review committee.

The population for the study was all mothers who had eligible young children (age 6 months to 35 months) and have been residents of the study area for more than six months. Exclusion criteria for this study were children of multiple pregnancies, children with evidence of chronic health problems such as diagnostically proven active tuberculosis, and symptomatic HIV/AIDS. Sampling size for the survey was determined using the single population proportion method corrected for population (< 10,000), and yielded 169 mothers and child pairs. 


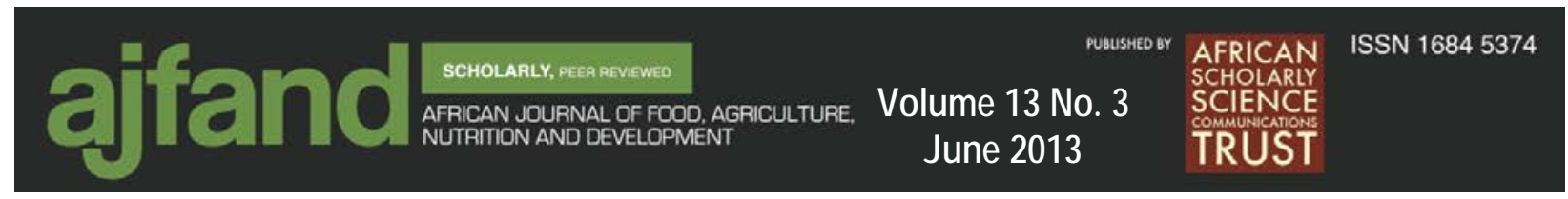

\section{Survey}

Survey questions were provided in the local language (Sidamigna). There were questions on socio-demographic characteristics, maternal and child characteristics, child feeding practices, and knowledge and practices related to consumption of broad beans. Five trained nurses administered the pre-test questionnaires. Weight, height and Mid-Upper- Arm Circumference (MUAC) were measured in duplicate on each child. Weight was measured using an electronic scale (Seca 770) with children wearing a light shirt of known weight. Length or height was measured to the nearest $0.1 \mathrm{~cm}$ using the Shorr measuring board without shoes. Mid-Upper- Arm Circumference (MUAC) was measured by using an arm circumference tape measure. Values for Z-scores for height (HAZ) and weight (WAZ) were calculated based on standard guidelines of WHO [16]. Oedema was assessed by applying medium thumb pressure on upper side of both feet for three seconds; and bilateral pitting oedema was considered an indicator of severe acute malnutrition. Stunted, underweight, and wasted were defined by Z-scores for HAZ, WAZ, and WHZ less than -2 standard deviations (SD) below median values [16].

To determine the diet diversity score, 24-hour recalls were conducted with mothers regarding their child's intake. This score was calculated using food categories based on the FAO guidelines for measuring individual dietary diversity [17]. Each of the following eight food categories was assessed, and presence of a food in each was scored as 1: grains, roots and tubers; legumes and nuts; vitamin A rich fruits and vegetables; other fruits and vegetables; meat, poultry, fish; eggs; milk and milk products; and foods cooked with fats and/or oils.

Semi-structured focus group discussions guide was used to conducted discussion with mothers in the community who were not participating in the background survey. Discussion helps to obtain in-depth information on mothers' attitudes and practices on child feeding and rearing practices and bean consumption. Grouping of participants into two groups $(n=10)$ was made based on number of children: those having at least four children in one group, and having fewer than four children in the second group. The latter group had more of the younger ( $<30 \mathrm{y}$ of age) mothers than the first group.

\section{Formulating the complementary food}

The main complementary food of the region was a porridge made from barley and maize. A standard recipe was identified, and to this porridge, broad beans at 10, 20, and $30 \%$ (g/100 g) were added. All foods were obtained from the local market and bought in $50 \mathrm{~kg}$ lots. Broad beans were washed and soaked in clean tap water for 12 hours. After draining, the beans were germinated at room temperature for 24 hours, rinsed, dried in the sun and roasted using an oven to further reduce anti-nutritive factors and improve the flavor of the final product. Processing was adapted from Ghavidel and Prakash [18]. The roasted broad beans were milled into flour. Maize was washed and then soaked in clean tap water for 4 hours, processed as stated above and finally milled. Barley grain was soaked for 8 hours and the bran layer was removed by using traditional pestle and mortar. After dehusking, it was sundried for 2

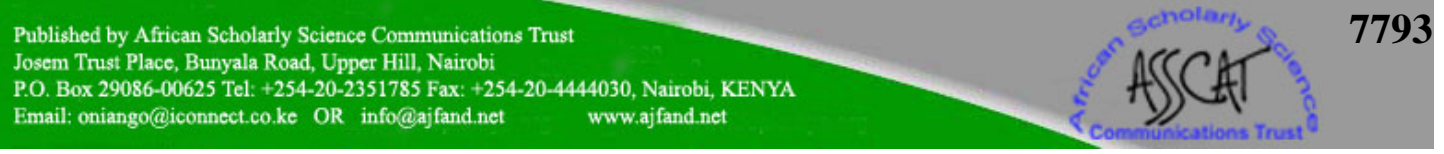




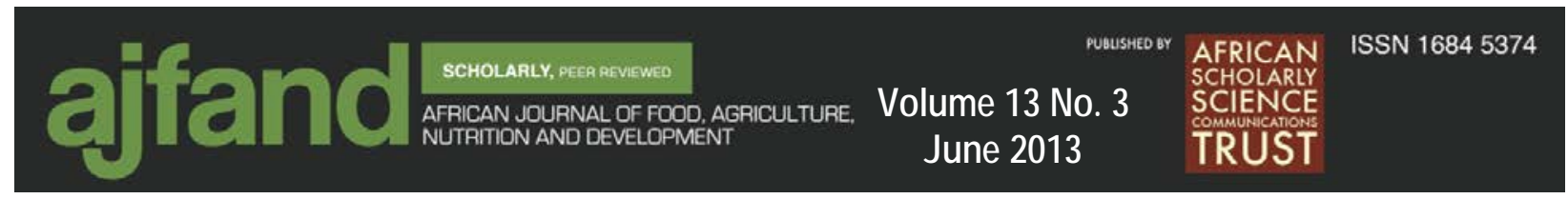

hours, roasted and then milled into flour. All milled samples were packed in airtight polyethylene plastic bags and stored at room temperature until needed.

Four versions of porridge were prepared. The barley-maize (control) porridge was prepared from barley and maize flour as follows: $70 \mathrm{~g}$ of barley and $30 \mathrm{~g}$ maize was blended and added to $300 \mathrm{ml}$ of boiling water, then cooked for 15 minutes. To make the $10 \%$ broad bean porridge, $10 \mathrm{~g}$ broad bean flour was mixed with $63 \mathrm{~g}$ barley and $27 \mathrm{~g}$ maize flour so that the ratio of barley and maize was not changed. The third porridge (20\% broad bean) was made with $20 \mathrm{~g}$ broad bean, $24 \mathrm{~g}$ maize and $56 \mathrm{~g}$ barley; and the $30 \%$ broad bean porridge was a mix of $30 \mathrm{~g}$ broad bean, $49 \mathrm{~g}$ barley, and $21 \mathrm{~g}$ maize.

Analysis of each unprocessed as well as processed food constituent and fresh food sample was done using standard AOAC methods [19]: moisture content (AOAC 925.09, 2000); ash content (AOAC 923.03, 2000); crude fiber content (AOAC 962.09, 2000); crude fat content: (AOAC 4.5.01, 2000); and crude protein (AOAC 979.09, 2000). Carbohydrate content was determined by difference. Gross energy was determined by calculation from fat, carbohydrate and protein content using the Atwater's conversion factor; $16.7 \mathrm{~kJ} / \mathrm{g}$ for protein, $37.4 \mathrm{~kJ} / \mathrm{g}$ fat and $16.7 \mathrm{~kJ} / \mathrm{g}$ forcarbohydrate. Iron and zinc contents were determined using atomic absorption spectrophotometer [20]. Phytate was determined by the method of Latta and Eskin [21] as modified by Vantraub and Lapteva [22].

\section{Acceptability Testing}

Acceptance testing was conducted with 30 mother-child pairs at Titecha. A 5-point Likert-like scale questionnaire was created containing the sensory elements to be asked: appearance, flavor, taste, color and consistency/mouth-feel. Each mother-child pair was given a measured sample (30 g) of each of the four porridges, in order of broad bean amount from lowest to highest. Mothers gave answers on behalf of their children based on each child's reaction (facial expression and general reaction) to the food offered, and these are the responses that are reported herein. Scores were averaged to obtain overall acceptability.

\section{Cost}

The cost of preparing the $30 \%$ broad bean product was determined using market prices that were prevalent at the time of the study.

\section{Statistical Analysis}

Analysis of data was conducted using SPSS version 16.0 and SAS 9.1. Descriptive statistics using frequencies, proportions and graphs were used to present the study results and differences were considered significant at $\mathrm{p}<0.05$. Means and standard deviations were calculated for acceptability of the sensory attributes of the complementary foods. Factorial analysis of variance (ANOVA) was conducted to test for significant differences $(p<0.05)$ in the sensory attributes between beansupplemented and traditional complementary foods. 


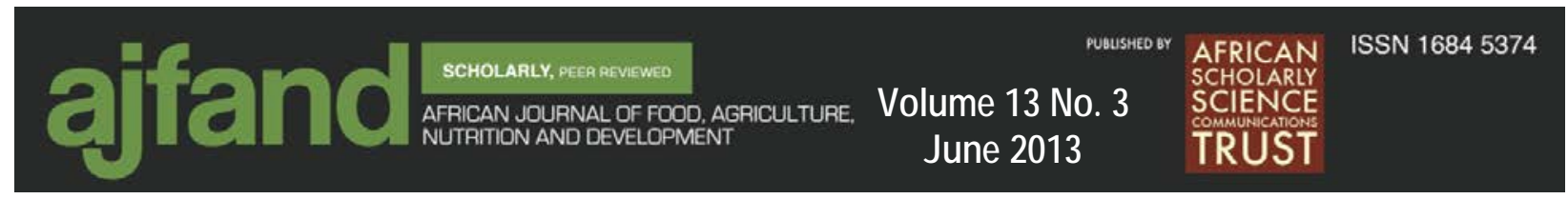

\section{RESULTS}

All mothers $(n=169)$ that were eligible when approached agreed to be interviewed. There were 86 (50.9\%) male and 83 (49.1\%) female children with a mean age of 19.4 \pm 9.3 months. There were 48 children aged 6 to 11 months, 58 children aged 12 to 23 months, and 63 children aged 24 to 35 months. The average number of children born to each mother was $4.1 \pm 2.3$. A majority of the mothers $(62 \%)$ were uneducated. Socioeconomic characteristics of study population are shown in Table 1. Farming (83\%) was the major source of income of the family, and monthly incomes of most households were under 250 Ethiopian birr, which is equivalent to less than \$1.50 USD per day. In the survey, 100 of 169 ( 60\%) mothers indicated rarely or never using beans, and reasons included not knowing its nutritive value (68\%), fearful that baby would not like it (18\%), cultural reason (such as forbidden traditionally) (9\%), and concern that beans can cause discomfort for the child (5\%).

The mean (SD) weight, height, and MUAC measures of children were 10.19 (2.28) $\mathrm{kg}, 78.46$ (9.19) $\mathrm{cm}$ and $13.36(1.09) \mathrm{cm}$, respectively. Stunting, wasting, and underweight were found in $22.5,4.7$, and $8.3 \%$ of the children, respectively. The mean (SD) for HAZ and WAZ scores of children were -1.12 (1.33) and -0.58 (1.11), respectively.

\section{Child Feeding Practices}

All study mothers reported having breastfed their children, with $72.8 \%$ of mothers currently breastfeeding those children identified for the study. Usual frequency for breastfeeding was eight times per 24 hours. Pregnancy was the most likely reason for stopping breastfeeding. Close to two-thirds of the mothers $(65.7 \%)$ reported the $6^{\text {th }}$ month after birth as the time of starting complementary feeding. The mean (SD) diet diversity score of study children was $2.1(0.7)$ out of a possible 8. Most frequently consumed food groups were grains, roots and tubers (97\%), followed by milk and milk products $(72 \%)$, and beans and nuts $(12 \%)$. None of the study participants consumed food groups for meat, poultry products and vitamin A rich fruits and vegetables the day before the study.

About $40 \%$ of mothers reported giving bean or pea-based food to their children. The most common reason (68\%) for not consuming these foods was not being aware of any advantage of using beans for children. Those who did use beans reported mixing them with other food items and frying. A small number (9\%) had the tradition of not using (cultural prohibition), while 18\% feared their child would not like these foods.

Production and consumption of bean crops in the area was a topic in focus group discussions. Most respondent mothers were producing a bean or pea crop; however, the production was on a small scale compared with cereals and other crops, and there was no separate land for its production. Mothers with fewer children, (the younger mothers) had a more positive outlook about using beans as food. When questioned about using beans and peas for their children, most participants had not experienced

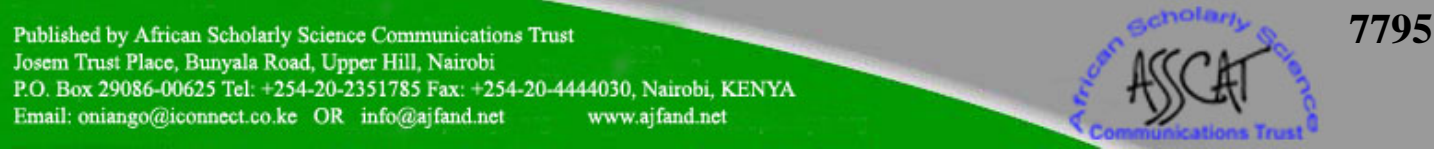




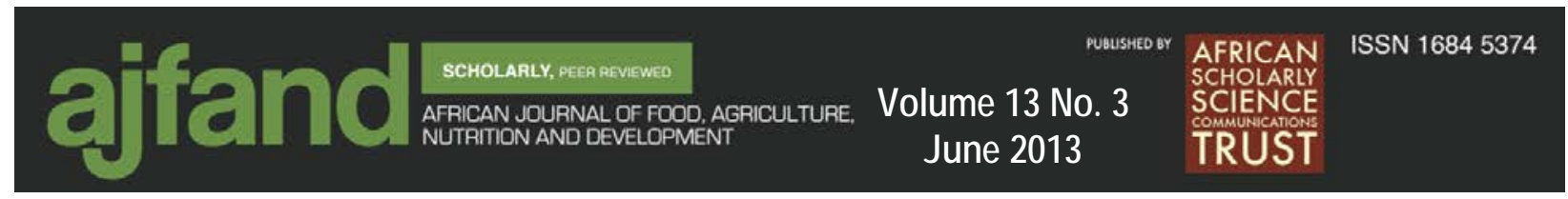

using it together with other cereals as complementary food. However, some expressed interest to do so but availability and affordability were important determinants.

\section{Composition of porridges}

Table 2 provides the levels of analyzed nutrients and other components in the porridges (data on raw ingredients not shown). The highest levels of protein and iron content were in the porridge made with $30 \%$ broad bean, wherein protein content increased by 6 grams per $100 \mathrm{~g}$. The lowest level of phytate was observed in the porridge made with $20 \%$ bean.

\section{Acceptability}

Porridge samples were evaluated for acceptance testing in the field where panelists were a subset of study mothers and children $(\mathrm{n}=30)$. For appearance, the highest mean score was given for sample prepared from only barley and maize (control) and the lowest score was for that of $30 \%$ broad bean. The $10 \%$ broad bean scored the highest for flavor and taste. The least score for flavor and taste was given to the $30 \%$ broad bean. The differences were significant $(\mathrm{p}<0.05)$ for appearance, flavor and taste. Overall, however, there were no significant differences in acceptability of any of the porridges.

\section{DISCUSSION}

In this study, the $1985 \mathrm{FAO} / \mathrm{WHO} / \mathrm{UNU}$ [13] recommendation for adding up to a maximum of $40 \%$ legumes to cereal-based complementary food for young children was tested for feasibility in a rural setting in Southern Ethiopia where despite the growing of broad beans as a crop, little incorporation of this food into complementary feeding was practiced. Similar high non-consumption of pulse was reported in another study conducted in Ethiopia [5]. The major reason in the present study was lack of knowledge of its nutritional importance for young children. Inappropriate preparation and presentation method especially for young children was raised as problem in focus group discussion. Grain consuming as major source of food for young children is a concern because relying primarily on grain is associated with phytate-induced poor mineral bioavailability [23]. Hence, the present study was geared at acceptability, through developing and testing bean-fortified complementary food.

Barley and maize were used as base foods for the porridge, and this is a common complementary food. These crops are produced and consumed in the study area as well as in other parts of highland society. Additionally, they were relatively cheap in the local market. Broad bean was added to improve protein content of the formulated product, and improved bioavailability of iron and zinc were indirectly assessed by measuring a decrease in phytate content. Combined consumption of the cereals and the broad bean should ensure a better amino acid score [7]. In order to have the best nutrient outcome, all crops were processed with processing methods that would improve digestibility and absorption of minerals [24]. There was a 33\% decrease in phytate content in germinated broad beans (data not shown) indicating that this

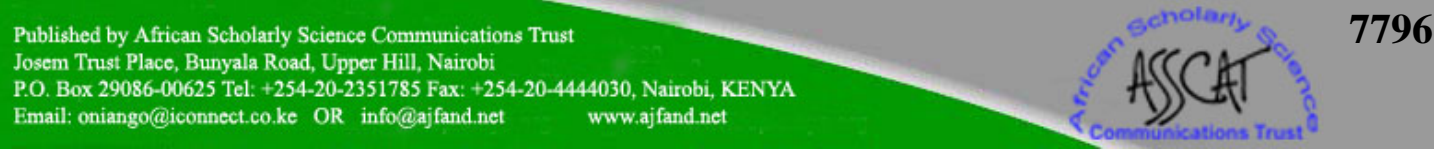




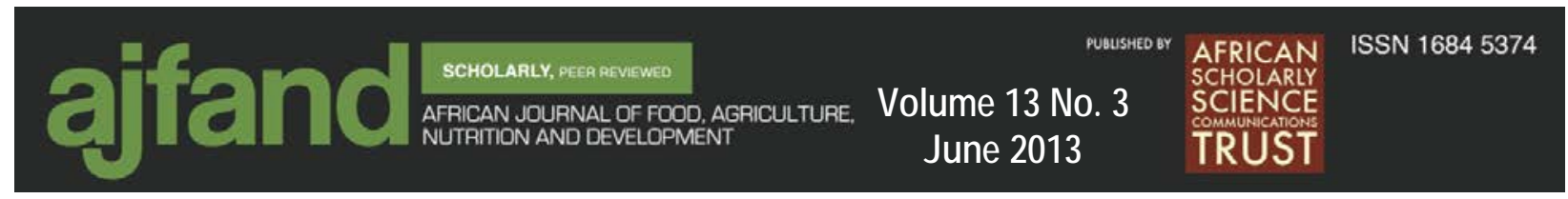

processing method possibly had similar phytate reduction effects for all the food components.

The increase in protein content of the porridges represented more than a $50 \%$ increase in protein content of the $30 \%$ broad bean product in comparision to the unfortified food. The iron and zinc contents were also improved, which is similar to a previously reported study findings carried out in the Sidama zone [25]. Preparation of $200 \mathrm{~g}$ of the $30 \%$ broad bean added porridge, a meal-size serving, cost four Ethiopian birr while similar amounts of complementary foods available in the market, cerefam (produced in Ethiopia) and cerelac (an imported Nestle product) each with similar content of protein, cost 20 and 56 Ethiopian birr, respectively. The product tested in this study, however, requires preparation of the raw ingredients.

Acceptability using sensory evaluation in the community by mothers and their young children showed no difference among the four porridges (Table 3). However, in terms of taste alone, there was a preference for the sample with $10 \%$ broad bean. Thus, an intervention trial involving product demonstration and tasting along with nutrition education to evaluate outcomes on sustained use and reduction in malnutrition indicators in this region is needed. The prevalence for stunting, wasting and underweight, were lower than the previous values of 44.4 , 9.7 and $28.7 \%$, respectively that were reported in a 2010 national survey [5]. Because the present study had exclusion criteria, data for seriously malnourished children were likely not included. Nevertheless, the present study suggests a serious malnutrition problem in the community, and reliance on cereal-based porridge with little dietary variety may be contributing to this situation.

\section{CONCLUSION}

Based on findings from this study, the majority of children had diets in the unacceptable range ( $\leq 3$ food groups), indicating most of them were not consuming a diversified diet needed for adequate growth and development. Additionally, most mothers were preparing food in the form of a low protein cereal-based gruel. Although grown in the area, broad beans with higher protein content than cereal grains were not widely consumed. The formulation of a broad bean-containing porridge as complementary food produced a higher protein food with acceptable sensory characteristics when compared to the customary cereal-based porridge of the region. This study demonstrated successful use of locally-available and affordable foods to enhance nutritional quality of complementary foods.

\section{RECOMMENDATION}

The authors recommend continuous nutrition education in consumption of diversified foods that include pulse and other legumes in order to enhance daily protein supplies. Further research is also necessary to document effectiveness of this type of beanfortified complementary food formulation.

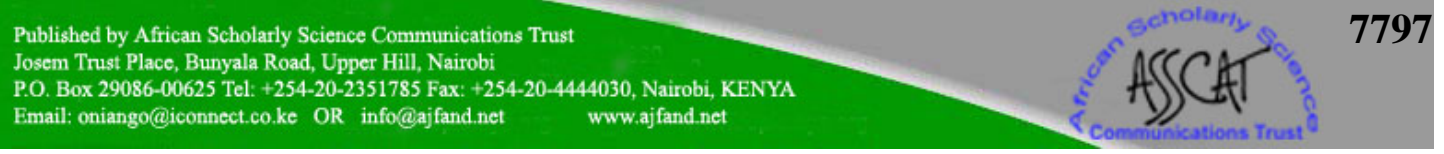




\section{ACKNOWLEDGMENTS}

The Canadian International Food Security Research Fund (CIFSRF) project which is funded by Canadian International Development Agency (CIDA) and International Development Research Center (IDRC) provided financial grant to the research work. 
Tabel 1: Socioeconomic, material and child characteristic of study participants mothers and children at Titecha Kebele Sidama Zone SNNPR

\begin{tabular}{|c|l|l|}
\hline Means of income & $\mathbf{N}$ & $\mathbf{\%}$ \\
\hline Private farming & 141 & 83.4 \\
\hline Self and government employed & 23 & 13.6 \\
\hline Daily laborers & 5 & 3 \\
\hline Monthly income* & & \\
\hline$<250$ birr & 87 & 51.5 \\
\hline $251-500$ & 37 & 21.9 \\
\hline $501-1000$ & 33 & 19.5 \\
\hline$>1001$ birr & 12 & 7.1 \\
\hline
\end{tabular}

*1 birr is \$0.06US in 2010 
Table 2: Mean (SD) proximate, phytate and mineral contents of barley-maize porridges supplemented with varying amounts of broad bean

\begin{tabular}{|c|c|c|c|c|}
\hline Component & $\begin{array}{l}\text { Control } \\
\text { Porridge }\end{array}$ & $\begin{array}{l}\text { Porridge } \\
+10 \% \text { Bean }\end{array}$ & $\begin{array}{c}\text { Porridge } \\
+20 \% \text { Bean }\end{array}$ & $\begin{array}{l}\text { Porridge } \\
+30 \% \text { Bean }\end{array}$ \\
\hline & \multicolumn{4}{|c|}{ Content of porridge per $100 \mathrm{~g}$ as prepared } \\
\hline $\begin{array}{l}\text { Protein } \\
\text { (g) }\end{array}$ & $11.2(0.4)^{\mathrm{d}}$ & $13.2(0.3)^{\mathrm{c}}$ & $15.2(0.7)^{\mathrm{b}}$ & $17.2(0.4)^{\mathrm{a}}$ \\
\hline $\begin{array}{l}\text { Fat } \\
\text { (g) }\end{array}$ & $1.7(0.4)$ & $1.5(0.5)$ & $1.6(0.4)$ & $1.3(0.9)$ \\
\hline $\begin{array}{l}\text { CHO } \\
\text { (g) }\end{array}$ & 74.4 & 73.1 & 70.9 & 68.7 \\
\hline $\begin{array}{l}\text { Energy } \\
\text { (kcal) }\end{array}$ & 357 & 358 & 367 & 356 \\
\hline $\begin{array}{l}\text { Fiber } \\
\text { (g) }\end{array}$ & $2.4(0.6)$ & $2.8(0.2)$ & $3.0(0.3)$ & $3.2(0.7)$ \\
\hline $\begin{array}{l}\text { Ash } \\
\text { (g) }\end{array}$ & $1.7(0.31)$ & $1.86(0.25)$ & $2.07(0.55)$ & $2.23(0.34)$ \\
\hline $\begin{array}{l}\text { Moisture } \\
\text { (g) }\end{array}$ & $10.9(0.2)$ & $10.5(0.8)$ & $10.3(0.6)$ & $10.5(0.4)$ \\
\hline $\begin{array}{l}\text { Phytate } \\
\text { (mg) }\end{array}$ & $89.4(0.8)^{\mathrm{C}}$ & $95.4(0.5)^{\mathrm{a}}$ & $88.3(0.3)^{\mathrm{C}}$ & $93.4(0.6)^{b}$ \\
\hline $\begin{array}{l}\text { Iron } \\
\text { (mg) }\end{array}$ & $4.82(0.20)^{\mathrm{C}}$ & $5.13(0.45)^{\mathrm{C}}$ & $5.67(0.40)^{b}$ & $7.88(0.32)^{\mathrm{a}}$ \\
\hline
\end{tabular}

Values in rows with different letters are significantly different $(\mathrm{p}<0.05)$. Only a priori tests are shown 
Table 3: Mother-child pair-defined $(n=30)$ sensory attributes and acceptability of barley-maize porridges made with varying amounts of broad bean. Values provided as mean (SD)

\begin{tabular}{|l|c|c|c|c|c|c|}
\hline \multicolumn{1}{|c|}{ Food } & Appearance* & Flavor* & Taste* & $\begin{array}{c}\text { Mouth } \\
\text { Feel* }^{*}\end{array}$ & Color* $^{*}$ & Acceptability $^{\#}$ \\
\hline $\begin{array}{l}\text { Control } \\
\text { Porridge }\end{array}$ & $4.55^{\mathrm{a}}$ & $\begin{array}{c}4.22^{\mathrm{b}} \\
(0.57)\end{array}$ & $\begin{array}{c}3.76^{\mathrm{b}} \\
(0.64)\end{array}$ & $\begin{array}{c}3.73^{\mathrm{a}} \\
(0.61)\end{array}$ & $\begin{array}{c}4.22^{\mathrm{a}} \\
(0.57)\end{array}$ & $\begin{array}{c}(0.58) \\
\left(0.62^{\mathrm{b}}\right.\end{array}$ \\
\hline $\begin{array}{l}\text { Porridge } \\
+ \text { 10\% }\end{array}$ & $4.52^{\mathrm{a}}$ & $4.33^{\mathrm{a}}$ & $3.80^{\mathrm{a}}$ & $3.75^{\mathrm{a}}$ & $4.17^{\mathrm{a}}$ & $4.40^{\mathrm{a}}$ \\
broad & $(0.54)$ & $(0.54)$ & $(0.55)$ & $(0.57)$ & $(0.53)^{\mathrm{a}}$ & $(0.53)$ \\
bean & & & & & & \\
\hline Porridge & $4.38^{\mathrm{b}}$ & $4.03^{\mathrm{b}}$ & $3.58^{\mathrm{c}}$ & $3.50^{\mathrm{b}}$ & $4.08^{\mathrm{a}}$ & $4.20^{\mathrm{b}}$ \\
$+20 \%$ & $(0.56)$ & $(0.58)$ & $(0.53)$ & $(0.57)$ & $(0.50)$ & $(0.48)$ \\
broad & & & & & & \\
bean & & & & & & \\
\hline Porridge & $4.20^{\mathrm{b}}$ & $3.68^{\mathrm{c}}$ & $3.53^{\mathrm{c}}$ & $3.50^{\mathrm{b}}$ & $3.88^{\mathrm{b}}$ & $4.10^{\mathrm{b}}$ \\
$+30 \%$ & $(0.48)$ & $(0.54)$ & $(0.57)$ & $(0.50)$ & $(0.59)$ & $(0.51)$ \\
broad & & & & & & \\
bean & & & & & & \\
\hline
\end{tabular}

*Mothers rated these attributes

${ }^{\#}$ Children provided acceptability, the latter interpreted by mothers

Values with different superscript letters indicate significant difference at $\mathrm{p}<0.05$ 


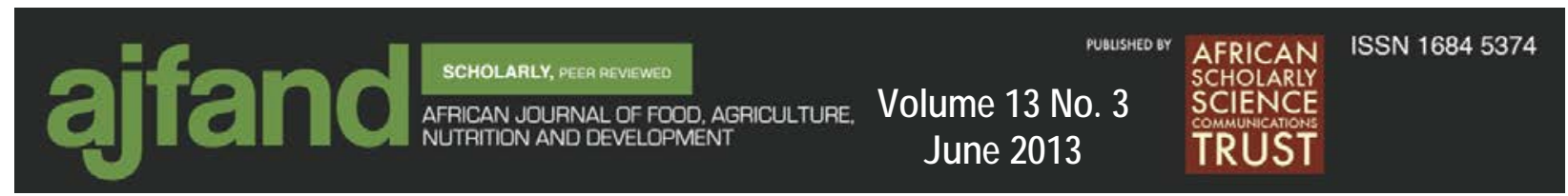

\section{REFERENCES}

1. Fottrell E, Enquselassie $\mathbf{F}$ and $\mathbf{P}$ Byass The distribution and effect of child mortality risk factors in Ethiopia: a comparison of estimates from DSS and DHS. Ethiopian J Health Develop 2009; 23: 163-168.

2. Woldemariam $\mathbf{G}$ and $\mathbf{T}$ Genebo Determinants of Nutritional Status of Women and Children in Ethiopia. Calverton, Maryland, USA: ORC Macro. 2002.

3. Mahgoub SEO Production and evaluation of weaning foods based on sorghum and legumes. Plant Foods for Human Nutrition 1999; 54: 29-42.

4. Allen LH Causes of Nutrition Related Public Health Problems of Preschool Children. J Pediat Gastroenterol Nutr 2006; 43: S8-S12.

5. Central Statistical Agency [Ethiopia] and ICF International Ethiopian Demographic and Health Survey 2011. Addis Ababa, Ethiopia and Calverton, Maryland, USA: Central Statistical Agency and ICF International 2012.

6. Dilis $\mathbf{V}$ and A Trichopoulou Nutritional and health properties of pulses. Mediterranean J Nutr Metab 2009; 1: 149-157.

7. Broughton WJ, Hernandeze G, Blair M, Beebe S, Gepts $P$ and $J$ Vanderleyden Beans are model food legumes. Plant and soil 2003; 225: 55128.

8. Egounlety M Production of legume-fortified weaning foods. Food Research International 2002; 35: 233-237.

9. Ethiopian Health and Nutrition Research Institute. Nutrition Baseline Survey 2009/10 Report for the National Nutrition Program of Ethiopia. Ethiopian Health and Nutrition Research Institute. Addis Ababa; Ethiopia. 2010.

10. Stoecker BJ, Abebe Y, Hubbs-Tait L, Kennedy TS, Gibson RS and I Arbide, et al. Zinc status and cognitive function of pregnant women in Southern Ethiopia. Eur J Clin Nutr 2009; 63: 916-918.

11. Gibson RS, Abebe Y, Hambidge MK, Abride I, Teshome A and BJ Stoecker Inadequate feeding practices and impaired growth among children from subsistence farming households in Sidama, Southern Ethiopia. J Maternal Child Nutr 2009; 5: 260-275.

12. Aubuchon-Endsley N, Grant S, Berhanu G, Thomas D, Schrader S, Eldridge $\mathbf{D}$, Kennedy $\mathbf{T}$, and $\mathbf{M}$ Hambidge Hemoglobin, Growth, and Attention of infants in Southern Ethiopia. Child Dev 2011; 82: 1238-1251. 
13. FAO/WHO/UNU Energy and Protein Requirements. Report of a Joint FAO/WHO/UNU Expert Consultation. Tech. Rept. Ser. No. 724. World Health Organization: Geneva, Switzerland. 1985.

14. Population Census Commission Census Summary and Statistical Report of the 2007 Population and Housing Census, Population census commission, Federal Democratic Republic of Ethiopia, Addis Ababa, Ethiopia. 2008.

15. Hula Woreda Administration Woreda administration sources, as quoted in Final Report for Aposto-Wendo-Negele. http://www-wds.World-Bank Org. Accessed on 15/02/2011.

16. Blossner M, Borghi SA, Onis M, Onyango A, and Yang H WHO Anthro for personal computers: software for assessing growth and development of the world's children. Geneva, Department of Nutrition for Health and Development: World Health Organization. 2007.

17. FAO Guidelines for measuring household and individual dietary diversity, version 4, Rome, Italy. 2008.

18. Ghavidel RA and $\mathbf{J}$ Prakash The impact of germination and dehulling on nutrients, anti-nutrients, in vitro iron and calcium bioavailability and in vitro starch digestibility of some legume seeds. LWT 2007; 40: 1292-1299.

19. AOAC. Official Methods of Analysis. (Vol. II $17^{\text {th }}$ ed.), of AOAC Association of Official Analytical Chemists, Washington, DC, USA. 2000.

20. AOAC. Official Methods of Analysis $4^{\text {th }}$ Edition; Association of Official Analytical Chemists (AOAC), Washington, DC, USA. 1984.

21. Latta $\mathbf{M}$ and $\mathbf{M}$ Eskin Simple and rapid colorimetric method for phytate determination. J Agricultural Food Chemistry 1980; 28: 1315-1317.

22. Vaintraub IA and NA Lapteva Colorimetric determination of phytate in unpurified extracts of seeds and the products of their processing. Analytical Biochemistry. 1988; 175: 227-230.

23. Abebe Y, Bogale A, Hambidge M, Stoecker BJ , Bailey K and RS Gibson Phytate, zinc, iron and calcium content of selected raw and prepared foods consumed in rural Sidama, Southern Ethiopia, and implications for bioavailability. J Food Composition Analysis 2007; 20: 161-168.

24. Hemalatha S, Platel $\mathbf{K}$ and $\mathbf{K}$ Srinivasan Influence of germination and fermentation on bio-accessibility of zinc and iron from grains. Eur J Clin Nutr 2007; 61: 342-384.

25. Abebe $\mathbf{Y}$, Stoecker BJ, Hinds $\mathbf{M J}$ and GE Gates Nutritive value and sensory acceptability of corn-and kocho-based foods supplemented with legumes for infant feeding in southern Ethiopia. African J of Food, Agriculture, Nutrition and Development, 2006; 6(1): 1-19. 